\title{
HIGH TEMPERATURE CORROSION STUDIES OF HVOF SPRAYED COATINGS IN MOLTEN SULPHATE SALTS ENVIRONMENT
}

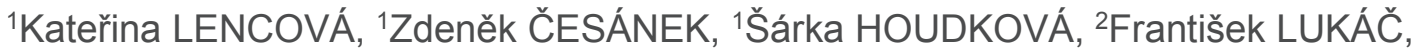 \\ ${ }^{2}$ Radek MUŠÁLEK
}

\author{
${ }^{1}$ Research and Testing Institute Pilsen, Pilsen, Czech Republic, EU, \\ lencova@vzuplzen.cz, cesanek@vzuplzen.cz,houdkova@vzuplzen.cz
}

2Institute of Plasma Physics of CAS, Prague, EU, musalek@ipp.cas.cz, lukac@ipp.cas.cz

https://doi.org/10.37904/metal.2019.885

\begin{abstract}
The generally applied requirements on lowering of emission production in the field of power industry have led, among others, into the application of low-emission combustion process of coal fired power plants. Besides the emissions reduction, this process has led to an increase of boilers parts corrosion degradation due to the reducing atmosphere in low-emission boilers, responsible for sulphide corrosion and molten salt attack. In such environment, the protection of the exposed surfaces gains importance. Among others, the thermal spraying technology can offer a suitable way of surface corrosion protection. In the present work, the high temperature corrosion behaviour of CoCrAIYTaCSi and $\mathrm{Cr}_{3} \mathrm{C}_{2}-25 \% \mathrm{NiCr}$ High Pressure/High Velocity Oxygen Fuel (HP/HVOF) sprayed coatings is evaluated and compared to the behaviour of bare structural steel (SPT360) substrate. The specimens were exposed to a molten salt environment, i. e., $12 \% \mathrm{Na}_{2} \mathrm{SO}_{4}+82 \% \mathrm{Fe}_{2}\left(\mathrm{SO}_{4}\right)_{3}$ at $690^{\circ} \mathrm{C}$ under cyclic condition, simulating the working environment in low-emission boilers of coal-fired power plants. The thermogravimetric method was used to establish the kinetics of corrosion. X-ray diffraction (XRD), scanning electron microscope (SEM) and energy dispersive spectroscopy (EDS) techniques were used to analyse the corrosion products and determine the corrosion mechanism. The thermogravimetric measurement shows high oxidation rate of SPT360 steel. $\mathrm{Cr}_{3} \mathrm{C}_{2}-25 \% \mathrm{NiCr}$ coating provides slightly better performance compared to CoCrAIYTaCSi coating. Based on the obtained results, both coatings were found to have higher corrosion resistance than the SPT360 steel substrate, offering a sufficient surface protection in a given environment.
\end{abstract}

Keywords: High temperature corrosion, low-emission boilers, coal fired boilers, HVOF, thermal spraying, CoCrAIYTaCSi, $\mathrm{Cr}_{3} \mathrm{C}_{2}-25 \% \mathrm{NiCr}$

\section{INTRODUCTION}

High temperature corrosion is an accelerated corrosion that occurs when metals and alloys are covered with thin film of molten salt. This complex salt deposit attacks protective oxide scale formed on the surface of the material. Combination of high temperature with presence of molten salt deposit leads to severe high temperature corrosion as observed e.g. in boilers, gas turbines, internal combustion engines and industrial waste incinerators [1-4]. The $12 \% \mathrm{Na}_{2} \mathrm{SO}_{4}+82 \% \mathrm{Fe}_{2}\left(\mathrm{SO}_{4}\right)_{3}$ corrosion environment is found in coal fired boilers [5, 7-9]. High temperature corrosion of coal fired boilers is caused by burning low grade fuel in combination with low emission combustion process. In order to decrease the amount of nitride oxides $\left(\mathrm{NO}_{\mathrm{x}}\right)$ emission production, modified low emission combustion process is applied which limits air excess at the burner exhaust area in the furnace chamber. The reducing gas environment results to sulphide corrosion and molten salt attack [4-6].

Due to the depletion of coal resources, low grade fuel with high impurities content is burned. Amounts and characteristic of coal impurities, such as sulphur, sodium, vanadium, and chlorine depends on the location of the coal mine. Sulphur is mainly contained in the coal in the form of iron sulphides, mostly ferrous disulphide 
$\mathrm{FeS}_{2}$. Sulphur can also be found in the form of organics compound combined with original coal constituent part and sulphates. During the combustion process, the ferrous disulphide $\mathrm{FeS}_{2}$ is mostly decomposed into iron and sulphur oxides. When the combustion occurs in a reducing atmosphere due to the limited air excess, there will be no complete decomposition and ferrous disulphide $\mathrm{FeS}_{2}$ forms ferrous sulphide FeS. The ferrous sulphide and iron interact and form an eutectic mixture with lower melting point which causes sintering. If the air deficit is too high, there is a high probability that ferrous sulphide will not react with iron. The ferrous sulphide is deposited on the boiler walls and causes sulphide corrosion. Generally, the sulphur is released from ferrous sulphide, reacts with oxygen and sulphur dioxide $\mathrm{SO}_{2}$ is being produced, that further partially oxidizes to sulphur trioxide $\mathrm{SO}_{3}$, see equitation 1 and $2[5,6]$.

$\mathrm{S}+\mathrm{O}_{2}=\mathrm{SO}_{2}$

$2 \mathrm{SO}_{2}+\mathrm{O}_{2}=2 \mathrm{SO}_{3}$

High temperature corrosion has two mechanisms: sulphite, which is caused by alkaline sulphates (sodium, potassium) and corrosion caused by complex sulphate compounds $\mathrm{Na}_{3} \mathrm{Fe}\left(\mathrm{SO}_{4}\right)_{3}$ and $\mathrm{K}_{3} \mathrm{Fe}\left(\mathrm{SO}_{4}\right)_{3}$, which are formed by alkaline sulphates and Iron (III) oxide $\mathrm{Fe}_{2} \mathrm{O}_{3}$ contained in fly ash. The latter corrosion mechanism is more important for coal boilers [6].

\section{Sulphitation:}

First, sodium is converted to sodium oxide $\mathrm{Na}_{2} \mathrm{O}$ and further reacts with sulphur trioxide $\mathrm{SO}_{3}$ to form sodium sulphate $\mathrm{Na}_{2} \mathrm{SO}_{4}$ (equitation 3 and 4). The resulting concentration of sodium sulphate $\mathrm{Na}_{2} \mathrm{SO}_{4}$ depends on the amount of sodium, because the concentration of sodium sulphate $\mathrm{Na}_{2} \mathrm{SO}_{4}$ is much smaller than sulphur trioxide $\mathrm{SO}_{3 .}[4,6]$.

$4 \mathrm{Na}+\mathrm{O}_{2}=2 \mathrm{Na}_{2} \mathrm{O}$

$\mathrm{Na}_{2} \mathrm{O}+\mathrm{SO}_{3}=\mathrm{Na}_{2} \mathrm{SO}_{4}$

Sodium sulphate $\mathrm{Na}_{2} \mathrm{SO}_{4}$ and / or potassium sulphate $\mathrm{K}_{2} \mathrm{SO}_{4}$ and iron oxide $\mathrm{Fe}_{2} \mathrm{O}_{3}$ deposited on the thermal apparatus reacts with $\mathrm{SO}_{3}$ contained in the flue gas and form complex compounds [3-6].

Corrosion caused by complex sulphate compounds:

$3 \mathrm{Na}_{2} \mathrm{SO}_{4}+\mathrm{Fe}_{2} \mathrm{O}_{3}+3 \mathrm{SO}_{3}=2 \mathrm{Na}_{3} \mathrm{Fe}\left(\mathrm{SO}_{4}\right)_{3}$

These complex compounds have a low melting point and react with the iron material of the boiler equipment.

$10 \mathrm{Fe}+2 \mathrm{Na}_{3} \mathrm{Fe}\left(\mathrm{SO}_{4}\right)_{3}=3 \mathrm{Fe}_{3} \mathrm{O}_{4}+3 \mathrm{FeS}+3 \mathrm{Na}_{2} \mathrm{SO}_{4}$

Ferrous sulphide $\mathrm{FeS}$ (right side of the equation) reduces to iron oxide $\mathrm{Fe}_{3} \mathrm{O}_{4}$ to and sulphur trioxide $\mathrm{SO}_{3}$. Sodium sulphate $\mathrm{Na}_{2} \mathrm{SO}_{4}$ (equitation 5) repeats the reaction. These complex compounds (equitation 6 ) $2 \mathrm{Na}_{3} \mathrm{Fe}\left(\mathrm{SO}_{4}\right)_{3}, \mathrm{~K}_{3} \mathrm{Fe}\left(\mathrm{SO}_{4}\right)_{3}$ and Iron (II) sulphide $\mathrm{FeS}$ undergo repeated corrosion process cyclically [6].

\section{MOLTEN SALT CORROSION TEST}

Cyclic high temperature corrosion test was performed on High Pressure/High Velocity Oxygen Fuel (HP/HVOF) sprayed coatings and bare structural steel (SPT360) substrate. CoCrAIYTaCSi and $\mathrm{Cr}_{3} \mathrm{C}_{2}-25 \% \mathrm{NiCr}$ coatings were deposited on the chromium-molybdenum steel substrate. The specimens were exposed to a molten salt environment $12 \% \mathrm{Na}_{2} \mathrm{SO}_{4}+82 \% \mathrm{Fe}_{2}\left(\mathrm{SO}_{4}\right)_{3}$ at $690{ }^{\circ} \mathrm{C}$ under cyclic condition, simulating the working environment in low-emission boilers of coal fired power plants. Each cycle comprised of $1 \mathrm{~h}$ of heating at $690^{\circ} \mathrm{C}$ in a silicon carbide furnace followed by 20 min cooling at room temperature 
for 50 cycles. For the high temperature test, samples of size $20 \times 20 \times 5 \mathrm{~mm}$ were used. The exposed surface of the tested specimens were polished down to $\mathrm{Ra}=1 \mu \mathrm{m}$. Salt coating deposit of $12 \% \mathrm{Na}_{2} \mathrm{SO}_{4}+82 \% \mathrm{Fe}_{2}\left(\mathrm{SO}_{4}\right)_{3}$ uniform thickness weighting $3-5 \mathrm{mg} / \mathrm{cm}^{2}$ was applied with a camel hairbrush on the preheated samples. The specimens were placed to a crucible boats. The resistance of tested specimens to the high temperature corrosion was evaluated using the thermogravimetric method to determine the kinetics of corrosion products. X-ray diffraction (XRD), scanning electron microscope (SEM) and energy dispersive spectroscopy (EDS) techniques were used to analyse the corrosion products and determine the corrosion mechanism. Diffractometer D8 Discover (Bruker), SEM EVO MA 15 (Carl Zeiss) and EDS Quantax XFlash 5010 (Bruker) were used for these tasks, respectively. Cross-sections were prepared by standard metallographic procedure using semi-automated Tegramin 25 (Struers) polishing system.

\section{RESULTS}

\subsection{Corrosion kinetic}

High temperature corrosion resistance of the tested specimens to the $12 \% \mathrm{Na}_{2} \mathrm{SO}_{4}+82 \% \mathrm{Fe}_{2}\left(\mathrm{SO}_{4}\right)_{3}$ molten salt environment was determined on the base of thermo-gravimetric method. Weight change measurements were performed after each testing cycle to establish the kinetics of corrosion. Weight gain graph for CoCrAlYTaCSi and $\mathrm{Cr}_{3} \mathrm{C}_{2}-25 \% \mathrm{NiCr}$ coatings and bare SPT360 steel substrate after exposure to the corrosion environment is shown in Figure 1.

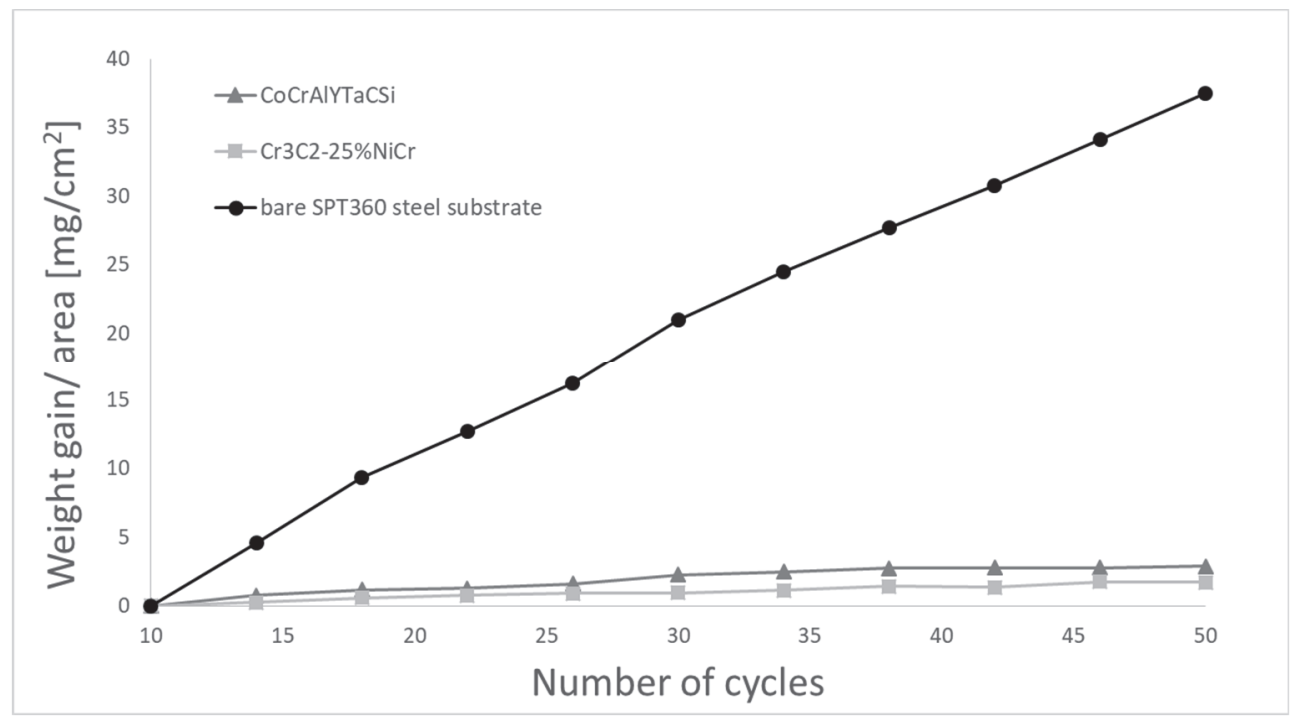

Figure 1 Weight gain versus the number of test cycles graph for CoCrAlYTaCSi and $\mathrm{Cr}_{3} \mathrm{C}_{2}-25 \% \mathrm{NiCr}$ coatings and and bare SPT360 steel substrate after the exposure to the $12 \% \mathrm{Na}_{2} \mathrm{SO}_{4}+82 \% \mathrm{Fe}_{2}\left(\mathrm{SO}_{4}\right)_{3}$ corrosion environment

The first 10 testing cycles of the high temperature corrosion test are not recorded in the weight gain graph because the corrosion behaviour of the samples was affected by the formation of the passivation oxide layer and the test stabilization. Weight gains that were observed during the high temperature corrosion test were caused by the formation of corrosion products. The best corrosion resistance was shown by the sample with the smallest oxidation rate. The bare SPT360 steel substrate showed a significant weight gain. The oxidation was substantial throughout the entire high temperature corrosion test. Against it, the HP/HVOF sprayed coatings showed insignificant weight gain and resisted to the corrosive environment throughout the whole testing period. $\mathrm{Cr}_{3} \mathrm{C}_{2}-25 \% \mathrm{NiCr}$ coating shown slightly smaller weight gain and thus provide better protection against high temperature corrosion than CoCrAlYTaCSi coating. 


\subsection{SEM and EDS cross-section analysis}

SEM and EDS techniques were used to analyse the corrosion products and determine the corrosion mechanism. The results of SEM and EDS analysis for CoCrAlYTaCSi and $\mathrm{Cr}_{3} \mathrm{C}_{2}-25 \% \mathrm{NiCr}$ coatings and bare SPT360 steel substrate in the cross section area after the exposure to the $12 \% \mathrm{Na}_{2} \mathrm{SO}_{4}+82 \% \mathrm{Fe}_{2}\left(\mathrm{SO}_{4}\right)_{3}$ aggressive corrosion environment are shown in the Figures 2-4.
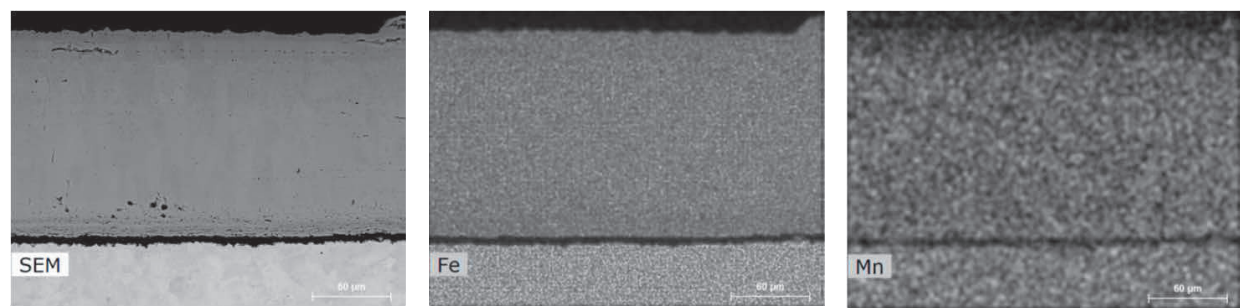

a) Elements of the substrate
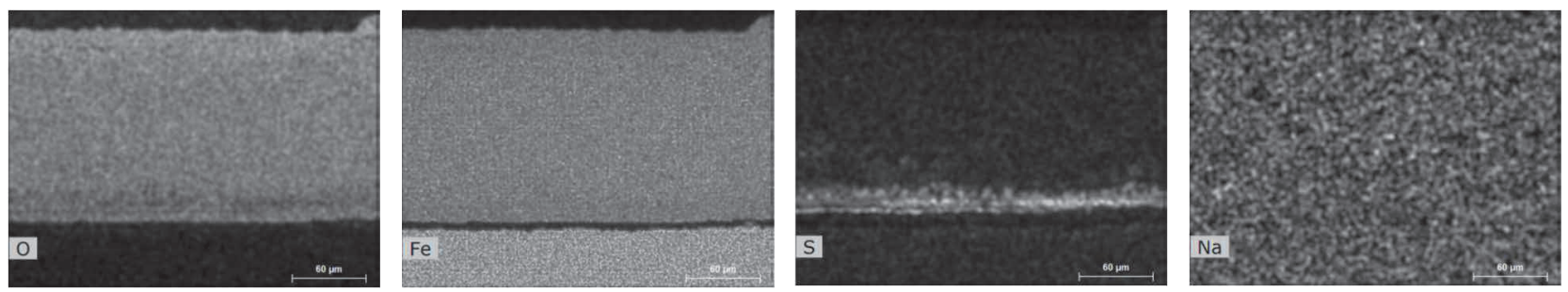

b) Corrosion elements

Figure 2 SEM photograph and EDS map of cross-section bare SPT360 steel substrate after the exposure to the $12 \% \mathrm{Na}_{2} \mathrm{SO}_{4}+82 \% \mathrm{Fe}_{2}\left(\mathrm{SO}_{4}\right)_{3}$ corrosion environment a) Elements of the substrate b) Corrosion elements
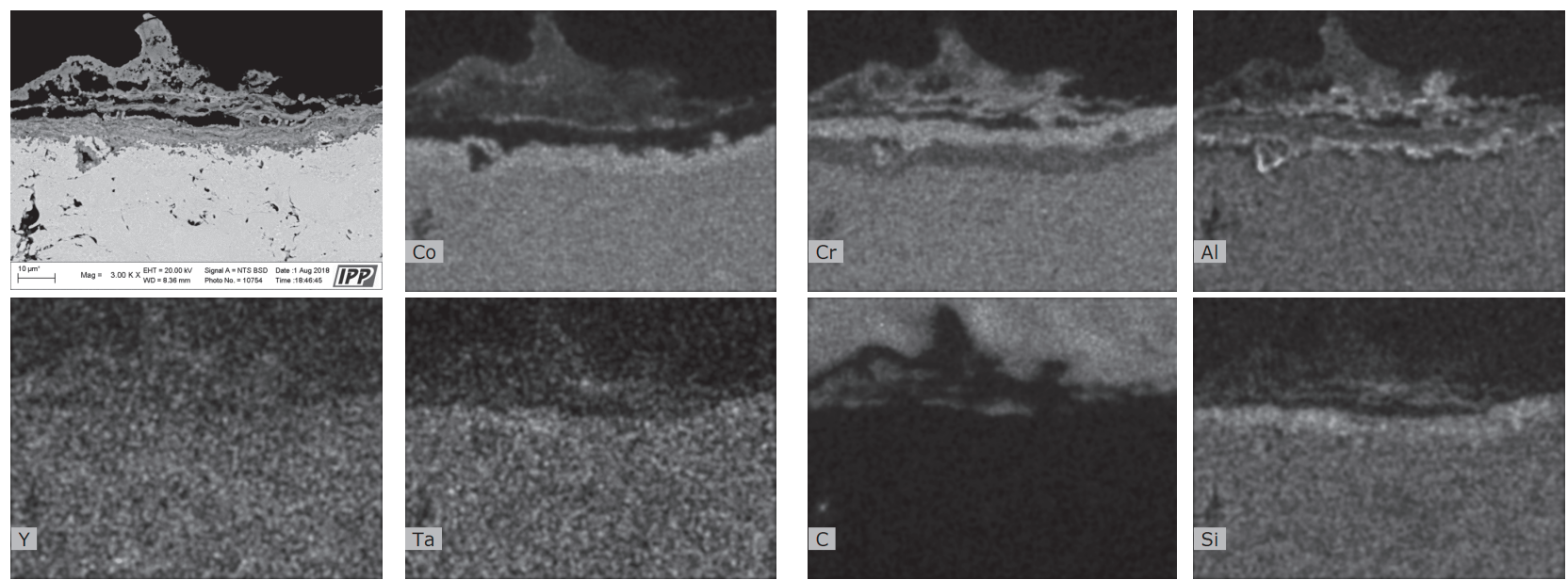

a) Coating elements
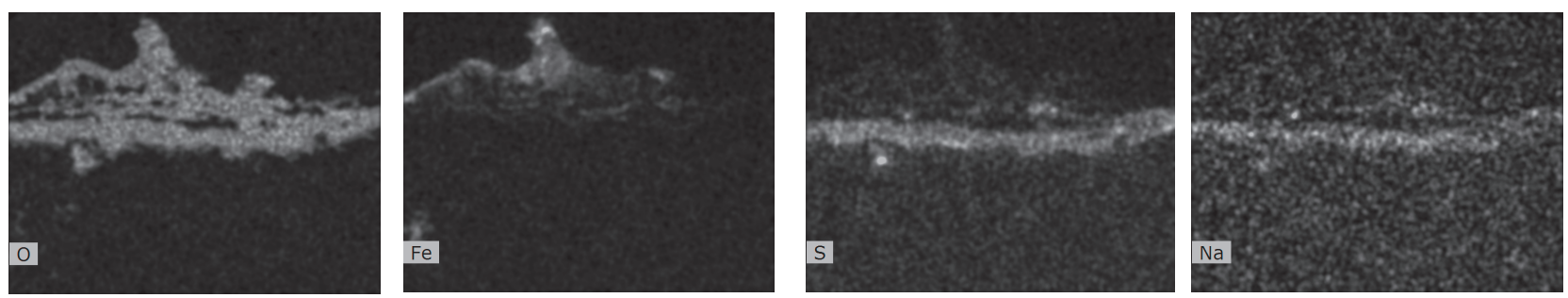

b) Corrosion elements

Figure 3 SEM photograph and EDS map of cross-section CoCrAIYTaCSi coating after the exposure to the $12 \% \mathrm{Na}_{2} \mathrm{SO}_{4}+82 \% \mathrm{Fe}_{2}\left(\mathrm{SO}_{4}\right)_{3}$ corrosion environment a) Elements of the substrate b) Corrosion elements 
The EDS analysis of bare SPT360 steel substrate (Figure 2) shows rather thick and delaminating the Fe and $\mathrm{O}$ rich scale, i.e. presence of iron oxides. The sulphur occurred in high concentration at the interface of the scale and the substrate. Corrosion attack of the CoCrAIYTaCSi coating is very uniform and the oxide layer is very thin. The EDS mapping results (Figure 3) show that all elements are evenly distributed in the coating structure with a greater concentration of $\mathrm{Cr}, \mathrm{Co}, \mathrm{Al}$ and $\mathrm{Si}$ at the corrosion layer and coating surface. According to EDS analysis for $\mathrm{Cr}_{3} \mathrm{C}_{2}-25 \% \mathrm{NiCr}$ coating, iron occurs on the surface of the corrosion layer, see Figure 4. At the interface of corrosion layer and coating surface is nickel depleted region. Sulphur occurred in a high concentration at the bottom of the oxide layer.
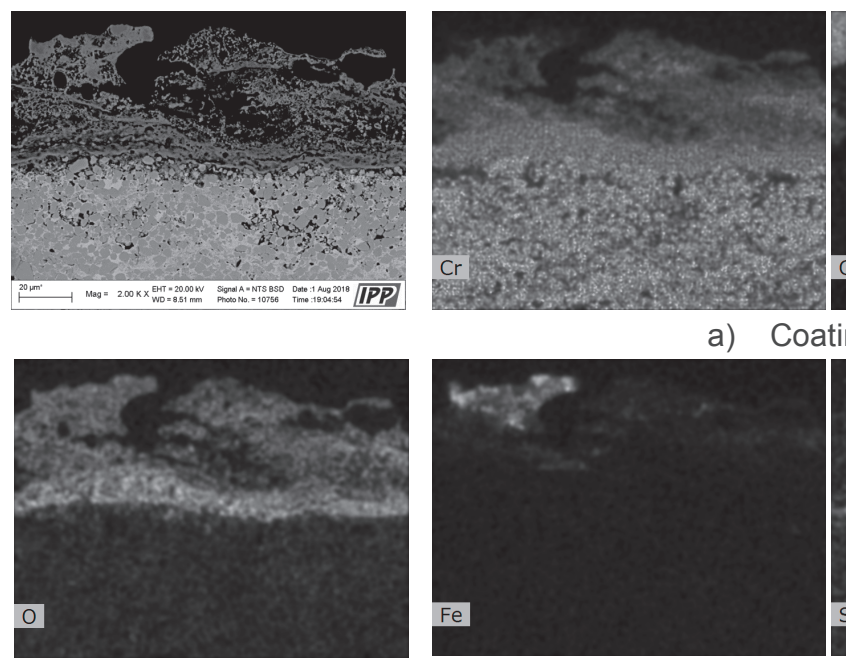

a) Coating elements
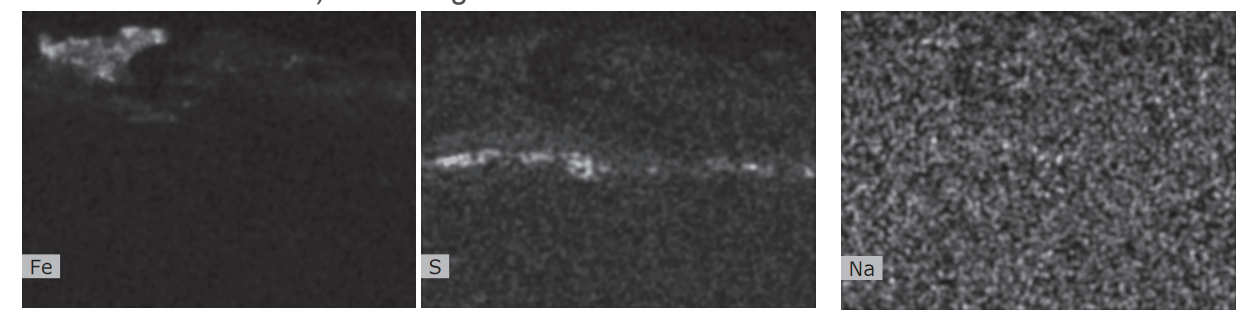

b) Corrosion elements

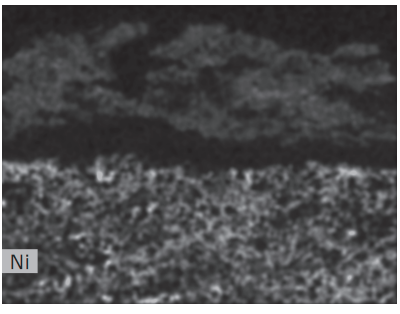

Figure 4 SEM photograph and EDS map of cross-section $\mathrm{Cr}_{3} \mathrm{C}_{2}-25 \% \mathrm{NiCr}$ coating after the exposure to the $12 \% \mathrm{Na}_{2} \mathrm{SO}_{4}+82 \% \mathrm{Fe}_{2}\left(\mathrm{SO}_{4}\right)_{3}$ corrosion environment a) Elements of the substrate b) Corrosion elements

\subsection{XRD analysis}

Results of XRD analysis of CoCrAlYTaCSi and $\mathrm{Cr}_{3} \mathrm{C}_{2}-25 \% \mathrm{NiCr}$ coatings and SPT360 steel substrate after exposure to the molten salt environment $12 \% \mathrm{Na}_{2} \mathrm{SO}_{4}+82 \% \mathrm{Fe}_{2}\left(\mathrm{SO}_{4}\right)_{3}$ are given in Table 1 . The XRD analysis was performed on the surface of the high temperature corrosion tested specimens gently cleaned from the corrosive medium. The X-ray diffraction pattern of the specimens after exposure is shown in Figure 5.

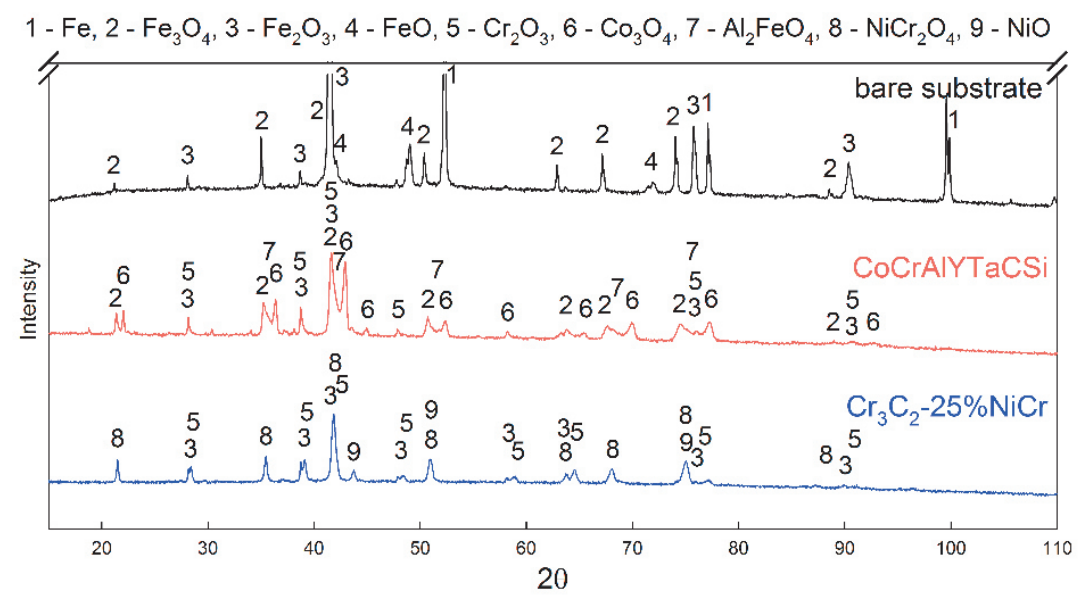

Figure 5 XRD results of CoCrAIYTaCSi and $\mathrm{Cr}_{3} \mathrm{C}_{2}-25 \% \mathrm{NiCr}$ coatings and and bare SPT360 steel substrate after the exposure to the $12 \% \mathrm{Na}_{2} \mathrm{SO}_{4}+82 \% \mathrm{Fe}_{2}\left(\mathrm{SO}_{4}\right)_{3}$ corrosion environment 
Table 1 XRD results for CoCrAIYTaCSi and $\mathrm{Cr}_{3} \mathrm{C}_{2}-25 \% \mathrm{NiCr}$ coatings and bare SPT360 steel substrate after exposure to the molten salt environment

\begin{tabular}{|c|c|c|}
\hline Sample & Majority phases & Minority phases \\
\hline CoCrAlYTaCSi & $\mathrm{Al}_{2} \mathrm{FeO}_{4}, \mathrm{Co}_{3} \mathrm{O}_{4}, \mathrm{Fe}_{3} \mathrm{O}_{4}$ & $\mathrm{Fe}_{2} \mathrm{O}_{3}, \mathrm{Cr}_{2} \mathrm{O}_{3}, \mathrm{Na}_{2} \mathrm{SO}_{4}, \mathrm{FeSO}_{4} 4 \mathrm{H}_{2} \mathrm{O}$ \\
\hline Cr3C2-25\%NiCr & $\mathrm{NiCr}_{2} \mathrm{O}_{4}, \mathrm{Cr}_{2} \mathrm{O}_{3}, \mathrm{Fe}_{2} \mathrm{O}_{3}$ & $\mathrm{NiO}$ \\
\hline Bare SPT360 steel & $\mathrm{Fe}, \mathrm{Fe}_{3} \mathrm{O}_{4}, \mathrm{Fe}_{2} \mathrm{O}_{3}$ & $\mathrm{FeO}$ \\
\hline
\end{tabular}

\section{DISCUSSION}

The aim of the present work was to evaluate and compare the high temperature corrosion resistance of CoCrAlYTaCSi and $\mathrm{Cr}_{3} \mathrm{C}_{2}-25 \% \mathrm{NiCr}$ High Pressure/High Velocity Oxygen Fuel (HP/HVOF) sprayed coatings and bare SPT360 steel substrate. All specimens were exposed to a molten salt environment $12 \% \mathrm{Na}_{2} \mathrm{SO}_{4}+$ $82 \% \mathrm{Fe}_{2}\left(\mathrm{SO}_{4}\right)_{3}$ at the temperature $690{ }^{\circ} \mathrm{C}$ under cyclic condition.

High temperature corrosion resistance of the tested specimens was determined by the thermo-gravimetric method. The method was established on the base of the kinetics of corrosion products. The corrosion behaviour of the first 10 testing cycles was affected by the formation of passivation oxide layer and the stabilization of the whole test. The coatings have shown the tendency to act as a diffusion barrier to the corrosive medium and successfully have retained its continuous contact with the substrate steel. The bare SPT360 steel substrate showed a high weight gain. The best high temperature corrosion resistance to the $12 \% \mathrm{Na}_{2} \mathrm{SO}_{4}+82 \% \mathrm{Fe}_{2}\left(\mathrm{SO}_{4}\right)_{3}$ environment showed $\mathrm{Cr}_{3} \mathrm{C}_{2}-25 \% \mathrm{NiCr}$ coating, which had the smallest weight gains during the test. CoCrAIYTaCSi coating shown slightly higher weight gain, nevertheless this coating showed high temperature corrosion resistance throughout the whole testing period too.

The XRD result shows the presence mainly of $\mathrm{Fe}_{3} \mathrm{O}_{4}, \mathrm{Fe}_{2} \mathrm{O}_{3}$ in the oxidized SPT360 steel substrate. The EDS analysis confirmed the presence of such upper oxide layer. The presence of large amount of the iron oxides with uniform distribution in the scale indicates no protective layer formation. The high concentration of the sulphur at the interface of the scale and substrate confirmed severe corrosion attack by $12 \% \mathrm{Na}_{2} \mathrm{SO}_{4} 82 \%$ $\mathrm{Fe}_{2}\left(\mathrm{SO}_{4}\right)_{3}$ molten salt environment.

The corrosion attack of the CoCrAIYTaCSi coating is very uniform. The EDS mapping results show that all elements are evenly distributed in the coating structure with a greater concentration of $\mathrm{Cr}, \mathrm{Co}, \mathrm{Al}$ and $\mathrm{Si}$ at the interface of corrosion layer and coating surface. According to the occurrence of oxygen can be concluded that these elements formed a corrosion barrier on the surface of the coating which prevented the action of the corrosive environment. The Fe and S possibly come from the molten salt environment which, diffuse towards the coating.

The oxide scale of $\mathrm{Cr}_{3} \mathrm{C}_{2}-25 \% \mathrm{NiCr}$ coating is mainly composed of nickel-chromium oxides $\mathrm{NiCr}_{2} \mathrm{O}_{4}$ and chromium oxide $\mathrm{Cr}_{2} \mathrm{O}_{3}$. The greatest concentration of these oxides is found the interface of the coating and the corrosion layer, which is evident from EDS mapping. In general, the presence of $\mathrm{Cr}_{2} \mathrm{O}_{3}$ oxide prevents oxidation of the coating. $\mathrm{Cr}_{2} \mathrm{O}_{3}$ works as a blocking barrier which prevents diffusion of corrosive environment to the inner matrix of alloys. The presence of $\mathrm{Fe}_{2} \mathrm{O}_{3}$ has been attributed to diffusion of corrosion environment. The Ni depleted region has formed at the interface of the coating surface and the oxide layer, meanwhile the $\mathrm{NiO}$ is primarily on the surface of the oxide layer.

\section{CONCLUSION}

This study investigated and compared the high temperature corrosion behaviour of $\mathrm{CoCrAlYTaCSi}$ and $\mathrm{Cr}_{3} \mathrm{C}_{2-}$ $25 \% \mathrm{NiCr}$ HP/HVOF sprayed coatings and bare SPT360 steel substrate. The specimens were exposed to the $12 \% \mathrm{Na}_{2} \mathrm{SO}_{4}+82 \% \mathrm{Fe}_{2}\left(\mathrm{SO}_{4}\right)_{3}$ molten salt environment at $690{ }^{\circ} \mathrm{C}$ under cyclic condition, simulating the working 
environment in low-emission boilers of coal fired power plants. All specimens were evaluated using thermogravimetric method to determine the kinetics of the corrosion. To analyse of the corrosion products and determine the corrosion mechanism, X-ray diffraction (XRD), scanning electron microscope (SEM) and energy dispersive spectroscopy (EDS) techniques were used.

The bare SPT360 steel substrate suffered severe corrosion attack. The results of analyses show high oxidation rate during exposure to the corrosion environment and presence of large amounts of the iron oxides. HP/HVOF sprayed coatings were found to have great high temperature corrosion resistance. The chromium rich oxide scale contributed to the improved high temperature corrosion resistance and the coatings have shown the tendency to act as diffusion barrier to the oxidizing species. $\mathrm{Cr}_{3} \mathrm{C}_{2}-25 \% \mathrm{NiCr}$ coating showed slightly better resistance to molten salt environment than CoCrAIYTaCSi coating.

\section{ACKNOWLEDGEMENTS}

\section{The paper has originated in the framework of institutional support for the long-time conception development of the research institution provided by Ministry of Industry and Trade of the Czech Republic.}

\section{REFERENCES}

[1] SIDHU, T.S., PRAKASH, S., AGRAWAL, R.D. Performance of high-velocity oxyfuel-sprayed coatings on an Febased superalloy in Na2SO4-60\%V2O5 environment at $900{ }^{\circ} \mathrm{C}$ part II: Hot corrosion behavior of the coatings, Tribology International, 2006, Vol. 15, pp 130-138. Available from: 10.1361/105994906X83411

[2] SIDHU, T.S., MALIK, A., PRAKASH, S. ET AL. Oxidation and Hot Corrosion Resistance of HVOF WC-NiCrFeSiB Coating on Ni- and Fe-based Superalloys at $800^{\circ} \mathrm{C}$, Journal of Materials Engineering and Performance, 2007 , Vol. 16, pp 844-849

[3] SIDHU, T.S., PRAKASH, S. and AGRAWAL, R.D. Hot corrosion and performance of nickel-based coatings, Tribology International, 2006, Vol. 90, pp. 41-47

[4] KOPELENTOVÁ, K., ČESÁNEK, Z. and SCHUBERT, J. Vysokoteplotní koroze MCrAIY povlaků aplikovaných technologií HVOF v korozním prostředí Na2SO4 - 60 \%V2O5, Vrstvy a povlaky 2017, 2017, pp. 51-55

[5] TOPOLSKA, S., LABANOWSKI, J. Corrosion of evaporator tubes in low emission steam, Archives of Materials Science and engineering, 2010, Vol. 42, pp. 85-92.

[6] ISHIGAI, S. Steam Power Engineering: Thermal and Hydraulic Design Principles, 1rd ed Cambridge University Press, 1999. p.189

[7] SINGH, H., KAUR, M., PRAKASH, S. High-temperature Exposure Studies of HVOF-Sprayed Cr3C225(NiCr)/(WC-Co) Coating, Journal of Thermal Spray Technology, 2016, Vol. 25, pp 1192-1207. Available from: DOI:10.1007/s11666-016-0424-6

[8] KAUR, M., SINGH, H., PRAKASH, S. Role of detonation gun spray Cr3C2-NiCr coating in improving high temperature corrosion resistance of SAE-213-T22 and SAE-347H steel in presence of Na2SO4-82\%Fe2(SO4)3 salt deposits, Surface Engineering, 2010, vol 26, pp 428-439. Available from: DOI: 10.1179/026708409X12490360425963

[9] KAUR, M., SINGH, H., PRAKASH, S. High-Temperature Corrosion Studies of HVOF-Sprayed Cr3C2-NiCr Coating on SAE-347H Boiler Steel, Journal of Thermal Spray Technology, 2009, Vol. 18, pp 619-632. Available from: DOI: 10.1007/s11666-009-9371-9 